\title{
Assessment of Inflammasome Activity in Type 2 Diabetes Mellitus and Simple Obesity: Comparative Study
}

\author{
Amna N. Jassim* SananTh. Abd-Alwahab* \\ Received 11, November, 2012 \\ Accepted 4, December, 2012
}

\begin{abstract}
:
Inflammasome is a multiprotein oligomer complex which is the precursor procaspase1 and is a component of the innate immune system so that this study aimed to determine the serum levels of interleukin- $1 \beta$ and 18 in patients with T2D and simple obesity in an attempt to clarify the role of inflammasome in these disorders.

Twenty five known cases of T2D, twenty four patients with simple obesity and twenty healthy subjects were randomly recruited from AL-Kindy Teaching Hospital in Baghdad to enroll in this study. All the data about the demographic characteristics and anthropometric measurements were determined in all patients, also the C-reactive protein and serum interleukin (IL)-1 $\beta$ and IL-18 levels were obtained from each patient. The results showed that patients who had positive C-reactive protein $(\geq 6$ $\mathrm{mg} / \mathrm{L}$ ) had significant high level of serum $1 \beta$ and IL-18 levels. Concomitant significant increase in serum levels of IL- $1 \beta$ and IL-18 was observed only in $8 \%$ (2 out of 25) of T2D. It concludes that the activity of inflammasome is observed in low percent of T2D and this activity does not related to the obesity.
\end{abstract}

\section{Key words: IL-1ß, IL-18, Inflammasome, type 2 diabetes, simple obesity}

\section{Introduction:}

Inflammasome is a multiprotein oligomer complex that comprises an intracellular sensor typically a Nodlike receptor which is the precursor procaspase-1 and the apoptosisassociated speck-like protein containing caspase activation and recruitment domain Inflammasome is considered a component of innate immune system. It is expressed in many cells including myeloid cells.As a result of inflammasome activation the mature IL-1 $\beta$ and IL-18 will release from cells [1]. Therefore, the inflammasome functions to cleave proIL-1 $\beta$ and pro-IL-18 into their active cytokines. Caspase 1 activation and release of IL-1 $\beta /$ IL-1 family members is central to the pathogenesis of many autoinflammatory syndromes, as evidenced by the effectiveness of anti-
IL-1 biologics in treating these disorders [2] Recent evidence pointed out the role of cytokines including IL1, IL-6 and tumor necrosis factor (TNF) in the pathogenesis of type 1 and 2 diabetes mellitus by destroying the $\beta$-cell of pancreas and increasing the cortisol release [3].In type 2 diabetes mellitus (T2D) complicated with atherosclerosis, the inflammasome is stimulated to activate IL-1 $\beta$ and IL-18. Inflammasomes are activated by certain triggers which included cholesterol crystles, high blood glucose, ceramide and islet amyloid polypeptide. [4] IL-1 involved in pathogenesis of obesity and insulin resistance [5].Stress can evoke signaling of IL-1 in subcutaneous adipose tissue which on the long term may cause visceral obesity [6].Obesity

*Department of Biology College of Science for Women University of Baghdad 
is characterized by low- grade chronic inflammation and IL-18 has been suggested as an adipogenic cytokine that is associated with excess adiposity i.e. IL-18 gene may have a role in the development of obesity [7]. This study was aimed to assess the activity of inflammasome in type 2 Diabetes and simple obesity in which low grade of inflammation played a role in their pathogenesis by determining the serum level of IL-1 $\beta$ and IL-18.

\section{Materials and methods:}

This study was done in the Department of Biology, College of Science for women - University of Baghdad, Iraq from November 2011 to April 2012. This study was approved by the Institutional Scientific Committee and a verbal consent was obtained from each patient enrolled in the study. Patients who eligible for the study were both gender and their ages ranged between 25 to 70 years. The criteria of inclusion were type 2 Diabetes and simple obesity patients. The criteria of exclusion were: acute or chronic infections, autoimmune disease, chronic renal failure, terminal illnesses and using non-steroidal antiinflammatory medications or steroids. The patients were recruited from the Consultant Clinic at Al-Kindy Teaching Hospital in Baghdad, Iraq. Information regarding the disease Waist-hip ratio $(\mathrm{w} / \mathrm{h})$ was calculated by dividing the waist circumference over hip circumference taking a ratio of $\geq$ 0.8 (in females) and $\geq 0.9$ (in males) as indication for central obesity [10]. Venous blood obtained from patients for determination of fasting serum glucose and hemoglobin Alc (\%), and then the sera were separated for determination of C-reactive protein and the other volume of serum was kept in chest-freezer $\left(-20^{\circ} \mathrm{C}\right)$ for further determination of IL-1 $\beta$ and IL-18 using illness obtained from each patient according to the specific questionnaire designed for each of the studied disease. All the patients were known cases of type 2 Diabetes and simple obesity, attended the hospitals for follow-up. A total number of 25 T2D patients, 24 simple obesity patients and 20 healthy subjects served as control group were admitted in the study.

After obtaining the information from each patient the anthropometric measurements were determined. These measurements included: weight $(\mathrm{kg})$, height $(\mathrm{m})$, waist circumference $(\mathrm{cm})$ and hip circumference $(\mathrm{cm})$. Body mass index was calculated according to the Quettlet's equation [8]:

Body mass index (BMI) $\left(\mathrm{kg} / \mathrm{m}^{2}\right)=$ Weight $(\mathrm{kg}) /$ height $\left(\mathrm{m}^{2}\right)$.

According to the value of the BMI, the obesity was categorized into the following classes. (Table-1) [9]:

Table-1 Categories of obesity in reference to body mass index

\begin{tabular}{|l|l|}
\hline Category & $\begin{array}{l}\text { Body mass index } \\
\left(\mathrm{kg} / \mathrm{m}^{2}\right)\end{array}$ \\
\hline Underweight & $<18.5$ \\
Normal & $18.5-24.9$ \\
Overweight & $25-29.9$ \\
Obese (class I) & $30-34.9$ \\
Obese (class II) & $35-39.9$ \\
Obese (class & $\geq 40$ \\
III) & \\
\hline
\end{tabular}

enzyme linked immunosorbent assay (ELISA).

\section{Statistical Analysis}

The results were expressed as number, percent and whenever possible as mean \pm SD. The data were analyzed using unpaired two tailed test taking $P \leq 0.05$ as the lowest limit of significance.

\section{Results:}

Table 2 shows the characteristics of the patients. The mean age of T2D patients was higher than corresponding healthy 
subjects $(P<0.001)$ or simple obesity patients. There was non-significant difference between T2D and simple obesity patients regarding their duration of illnesses. Fasting blood glucose was significantly higher in T2D and the $\mathrm{HbA}_{1 \mathrm{c}} \%$ was at the border line of diabetic control.

While table- 3 shows that $86 \%$ of T2D (17 out of 25) were obese compared with control and central obesity was observed in $84.6 \%$ of female cases (11 out of 13 patients) and $41.7 \%$ of male cases (5 out of 12 patients). In simple obesity patients, the central obesity was observed in $95.8 \%$ of cases (23 out of 24 patients). C-reactive protein $(\geq 6$ $\mathrm{mg} / \mathrm{L}$ ) was observed in $60 \%$ (15 out of 25 ) of T2D and $41.7 \%$ (10 out of 24) of simple obesity patients which did not reach to the significant level (Table 4). The activity of inflammasome was detected only in $8 \%$ of T2D ( 2 out of $25)$ by the evidence of concomitant detection high level of serum IL-1 $\beta$ and IL-18 (Table 4). Serum level of IL$1 \beta$ was significantly elevated in $12.5 \%$ (3 out of 24 cases) of simple obesity patients compared with $32 \%$ (8 out of 25 cases) of T2D. All patients presented with detected levels of serum IL-1 $\beta$ and IL-18 had significant positive $\mathrm{C}$-reactive protein test i.e. $\geq 6$ $\mathrm{mg} / \mathrm{L}$.

Table-2 Characteristics of the study

\begin{tabular}{|c|c|c|c|}
\hline Category & $\begin{array}{c}\text { Healthy subjects } \\
(\mathrm{n}=20)\end{array}$ & $\begin{array}{c}\text { Type } 2 \\
\text { Diabetes } \\
(\mathrm{n}=25)\end{array}$ & $\begin{array}{c}\text { Simple } \\
\text { obesity } \\
(\mathrm{n}=24)\end{array}$ \\
\hline Gender (Male: Female) & $8: 12$ & $12: 13$ & $10: 14$ \\
Age (year) & $46.3 \pm 6.3$ & $56.8 \pm 7.5 *$ & $41.4 \pm 12.3$ \\
Duration of disease (year) & - & $12.12 \pm 5.7$ & $8.66 \pm 6.62$ \\
Fasting blood glucose (mg/dl) & $98.4 \pm 2.2$ & $132.8 \pm 19.9 *$ & $101.3 \pm 3.2$ \\
Hemoglobin A1c (\%) & $<5.8$ & $6.8 \pm 1.3$ & $<6.0$ \\
\hline
\end{tabular}

Table-3 Distribution of individuals according to the anthropometric measurements

\begin{tabular}{|l|c|c|c|}
\hline \multicolumn{1}{|c|}{ Category } & $\begin{array}{c}\text { Healthy } \\
\text { subjects } \\
(\mathrm{n}=20)\end{array}$ & $\begin{array}{c}\text { Type } 2 \\
\text { Diabetes } \\
(\mathrm{n}=48)\end{array}$ & $\begin{array}{c}\text { Simple } \\
\text { obesity } \\
(\mathrm{n}=24)\end{array}$ \\
\hline Body mass index & $22.5 \pm 1.3$ & $33.95 \pm 8.2$ & $38.53 \pm 7.3$ \\
Underweight & 0 & 0 & 0 \\
Normal & 20 & 3 & 0 \\
Overweight & 0 & 5 & 0 \\
Obese (class I) & 0 & 7 & 8 \\
Obese (class II) & 0 & 4 & 7 \\
Obese (class III) & 0 & 6 & 9 \\
Waist/hip ratio & $0.73 \pm 0.03$ & $0.918 \pm 0.128$ & $0.919 \pm 0.053$ \\
Waist/hip $\geq 0.8$ (female) & 0 & 11 & 13 \\
Waist/hip $\geq 0.9$ (male) & 0 & 5 & 10 \\
\hline
\end{tabular}


Table-4 Evidence of inflammasome activity

\begin{tabular}{|l|l|l|l|}
\hline \multicolumn{1}{|c|}{ Category } & Healthy subjects & Type 2 Diabetes & $\begin{array}{l}\text { Simple } \\
\text { obesity }\end{array}$ \\
\hline Serum IL-1 $\beta(\mathrm{pg} / \mathrm{ml})$ & $0 / 20$ & $8 / 25$ & $3 / 25$ \\
Detected (No.) & & $10-270$ & $5-100$ \\
Range & 90 & 10 \\
Median & & $108.8 \pm 85.1$ & $38.3 \pm 53.5$ \\
Mean \pm SD & $0 / 20$ & & \\
SerumIL-18 (pg/ml) & & $2 / 25$ & 0 \\
$\begin{array}{l}\text { Detected (No.) } \\
\text { Detected level } \\
\text { C-reactive protein }(\geq 6 \mathrm{mg} / \mathrm{L})(\text { No. })\end{array}$ & $0 / 20$ & $41.54,44.7$ & \\
\hline
\end{tabular}

The results are expressed as number, percent and mean \pm SD. $* P<0.001$ compared with healthy subjects.

\section{Discussion:}

The results of this study demonstrate that inflammasome is involved in pathogenesis of out of twenty five (8\%) T2D patients and the significant high level of IL-1 $\beta$ concentration in T2D and to less extent in simple obesity indicated the role of these biomarkers in their pathogenesis. Low grade of inflammation is involved in T2D and simple obesity, and Creactive protein is considered as a marker of inflammation [11]. The majority of T2D patients presented in this study were obese and this morbidity is not the only factor that responsible for positive CRP in this study. [12] Reported that CRP level was significantly higher in subjects with T2D than those without diabetes, after adjustment the body mass index. Significant high serum level of IL-1 $\beta$ is detected in eight out of twenty five $(32 \%)$ T2D is unlikely attributed to the evidences of metabolic syndrome like obesity, high blood pressure [13]. On the other hand significant high serum IL-18 observed in two patients which indicated other co-morbidity shared T2D for this observation. Recent review highlights on the significant importance of IL-18 as a valid biomarker of diabetic nephropathy
[14]. Based on the subjective evidence, none of T2D patients had history of nephropathy, therefore, the significant high serum IL-18 reported in this study attributed to the role of inflammasome in the producing mature IL-18. There is a general consensus that obesity is an eminently inflammatory process and accompanied with changes in serum leptin, adiponectin and interleukin-6 [15]. There is no clear association between simple obesity and IL- $1 \beta$ but there is an association between obesity as a risk factor for other disorders and IL- $1 \beta$. For example the obesity (assessed by body mass index) of polycytic ovarian syndrome patients was positively correlated with serum IL- $1 \beta$ which was significantly increased in those patients [16]. On the other hand IL-18 wasn't detected in obese patients in this study. It has been suggested that IL-18 acts as adipogenic cytokine and is increased in excess adiposity. Recent study demonstrated the association of IL-18 gene polymorphism with body mass index [7]. It is unlikely inflammasome plays a role in this category of patients because concomitant elevation of serum IL-1 $\beta$ and Il-18 not observed in this study.

It concludes that the activity of inflammasome is observed in low percent of T2D and this activity does not related to the obesity. 


\section{References:}

1-Wen, H.; Ting, J.P.; and O'Neill, L.A. 2012. A Role for the NLRP3 Inflammasome in Metabolic Diseases-did Warburg Miss Inflammation? Nat. Immunol. 13(4):352-357.

2-Savic, S.; Dickie, L.J.; Wittmann, M. and Mc Dermott. 2012. Autoinflammatory syndromes and cellular responses to stress: Pathophysiology, diagnosis and new treatment perspectives Best Pract. Res. Clin. Rheumatol.26: 505-533.

3-Classen,J.B.2012.Review of evidence that epidemics of type 1 diabetes and type 2 diabetes/metabolic syndrome are polar opposite responses to iatrogenic inflammation. Curr. Diabetes Rev.8(6):413-418.

4-Masters, S.L.; Latz, E.; and O'Neill, L.A. 2011.The Inflammasome in Atherosclerosis and Type 2 Diabetes. Sci Transl Med. 3(81):117

5-Tack, C.J.;Stienstra， R.; Joosten, L.A.; and Netea, M.G. 2012. Inflammation links excess fat toinsulin resistance: The role of the interleukin-1 family. Immunol. Rev., 249(1):239-252.

6-Speaker Speaker,K.J.and Fleshner, M. 2012 Interleukin-1 \&beta,: A potential link between stress and the development of visceral obesity. BMC Physiol., 8(12):1-15.

7-Kim, H.L.; Cho, S.O.; Kim, S.Y.; Kim ,S.H.; Chung, W.S.; Chung, S.H.;Kim, S.S.; Ko, S.G.;Jeong, C.H.; Kim, S.J.; Hong, S.H.; and Um, J.Y. 2012Association of Interleukin-18 GenePolymorphism with Body Mass Index in Women. Repord Biol Endocrinol, 31 (10):16.

8- Frier, B.M.; Truswell, A.S.; Shepherd, J.; and De Looy, A. 1999 Diabetes Mellitus, and, Nutritional and Metabolic Disorders. In:
Davidson's Principles and, Practice of Medicine, Christophers Haslett; Edwin, R.Chilvers; John, A.A. Hunter; Nicholas, A. Boon (eds.), chapter 7,eighteenth edition, Churchill Livingstone, London, p.p 526-527.

9- World Health organization. Classification of obesity, 2004. World Health Organization, Geneva.

10- Picon, P.X.; Leitão, C.B.; Gerchman, F.; Azevedo, M.J.; Silveiro, S.P.; Gross, J.L.; and Canani, L.H. 2007 Waist Measure and Waist-to-Hip Ratio and Identification of Clinical Conditions of Cardiovascular Risk: Multicentric Study in Type 2 Diabetes Mellitus Patients. ArqBras Endocrinol Metabol 51(3):443-449.

11-Calle, M.C.; and Fernandez, M.L. 2012 Inflammation and Type 2 Diabetes.Diabetes Metab.38(3):183191.

12-Belfki, H.; Ben Ali, S.; Bougatef, S.; Ben Ahmed, D.; Haddad, N.; Jmal, A.; Abdennebi, M.;and Ben Romdhane, H 2012 Association between C-Reactive Protein and Type 2 Diabetes inTunisian Population. Inflammation. 35(2):684-689.

13-Marques-Vidal, P.; Bastardot, F.; Von Känel, R.; Paccaud, F.; Preisig, M.; Waeber, G.; andVollenweider, P. 2012 Association between Circulating Cytokine Levels, Diabetes and InsulinResistance in a Population-Based Sample (CoLaus study). Clin Endocrinol (Oxf). (inpress)

14-Hellemons, M.E.; Kerschbaum, J.; Bakker, S.J.; Neuwirt, H.; Mayer, B.; Mayer, G.; De Zeeuw,D.; Lambers Heerspink, H.J.; and Rudnicki, M. 2012Validity of Biomarkers PredictingOnset or Progression of Nephropathy in 2Diabetes: a Systematic 
Review.Patients with Type.Diabet Med 29(5):567-577

15-Aguilar Cordero, M.J.; González Jiménez, E.; Sánchez Perona, J.;Padilla Lopez, C.A. ; Alvarez Ferre, J.; Ocete Hita, E.; Rizo Baeza, M.;Guisado Barrilao, R.; and García Rivas, F. 2012. Obesity and its Relation with Markers of Inflammation and Erythrocyte Fatty
Acids in aGroup of Overweight Adolescents. Nutr Hosp. 27(1):161164.

16-Yang,Y.; Qiao, J.; and Li, M.Z. 2012 Correlation between Interleukin-1 and the Obesity ofPolycystic Ovary Syndrome. Zhonghua $\mathrm{Fu}$ Chan $\mathrm{Ke} \mathrm{Za}$ Zhi.47(1):9-13.

\section{تقيم فعالية الجسيم الالتهابي في داء السكري النمط الثاني والسمنة البسيطة (در في داعة مقارنة)}

$$
\text { سنن ثائر عبد/لوهاب }
$$

امنتة نصبف جاسمث*

*قتم علوم الحياة / كلية العلوم للبنات

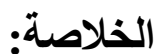

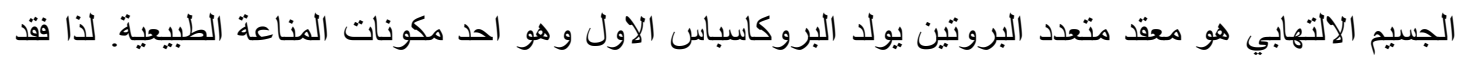

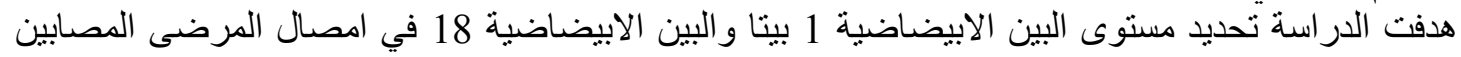

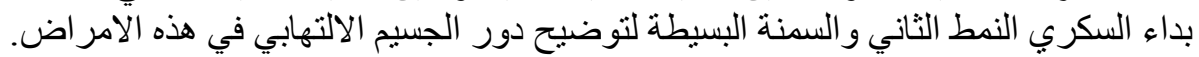

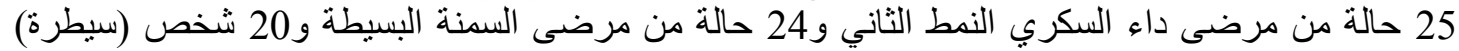

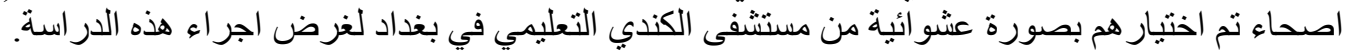

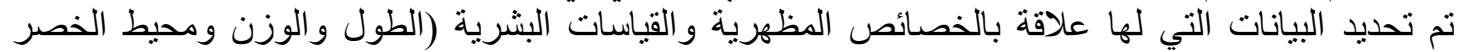

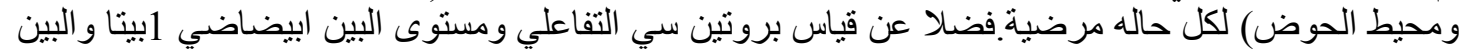

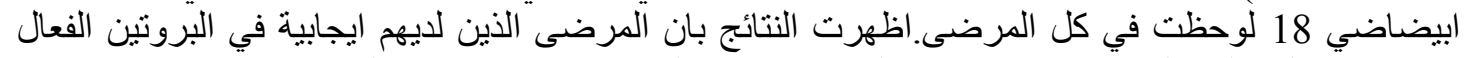

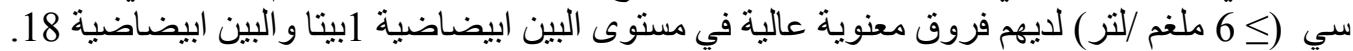

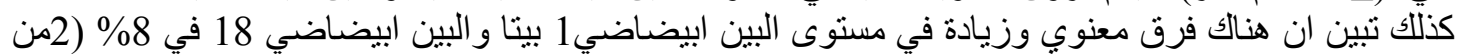

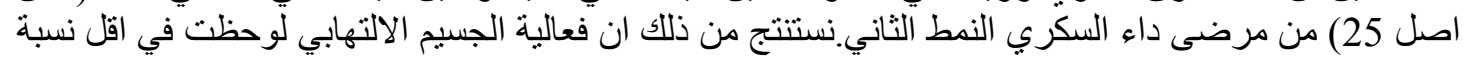

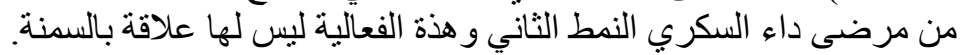

